\title{
Perancangan Robot Pemadam Api Wall Follower Beroda dengan Metode Fuzzy Logic (Studi Kasus : Simulasi Kebakaran pada Komplek Perumahan Citraland Kota Palu)
}

\author{
Albrecht Yordanus Erwin Dodu ${ }^{1)}$, Amriana ${ }^{2)}$, Firmansyah ${ }^{3)}$ \\ ${ }^{12) 3)}$ Program Studi Teknik Informatika, Jurusan Teknologi Informasi, Universitas Tadulako \\ Jl. Soekarno Hatta Km. 9 Palu, Sulawesi Tengah 94119 \\ Email : $\underline{\text { ayerwin.dodu@gmail.com }}{ }^{\text {) }}$, amrianaa23@gmail.com $^{2}$, firmansilverlist@gmail.com $^{3)}$
}

\begin{abstract}
One of the problems that robots can do in helping humans is putting out fires. This job requires a fast reaction, because fire can be avoided if the fire has not spread. Fire problems can be reduced if the source of the fire can be found first and extinguished in a short time. This research aims to design a prototype of a wheeled fire extinguisher robot by designing electronic components, mechanical parts and motion actuators on the robot and applying Sugeno fuzzy logic as the basis for the control system algorithm where the process starts from fuzzification, rule inference then defuzzification, and using the Wall Follower method as a method for navigation, because to support the optimum performance of the robot, a navigation system and a reliable design are needed. This robot uses the Arduino mega2560 as a microcontroller board, the ultrasonic sensor HC-SRO4 as a distance gauge, the fire sensor as a hotspot detector and the line sensor as a differentiator between home and target zone, while the software used in the robot programming is Arduino IDE. Robot testing is made using the blackbox method and aims whether the robot can extinguish the fire or not. The achievements of the results of this study are, implementing the fuzzy logic and wall follower method on firefighting robots so that the robot can search on arenas, extinguish fires on candles, stop and maintain an autonomous distance from walls.
\end{abstract}

Keywords : Robot, arduino, fire extinguisher, Sugeno fuzzy logic, wall follower

\begin{abstract}
ABSTRAK
Salah satu masalah yang dapat dikerjakan robot dalam membantu manusia adalah memadamkan api. Pekerjaan ini membutuhkan reaksi yang cepat, karena kebakaran dapat dihindari apabila api belum menyebar. Masalah kebakaran dapat dikurangi apabila sumber api dapat ditemukan terlebih dahulu dan dipadamkan dalam waktu yang singkat. Penelitian ini bertujuan untuk merancang sebuah prototype robot pemadam api beroda mulai dengan merancang komponen - komponen elektronika, bagian mekanik serta aktuator gerak pada robot dan merapkan metode fuzzy logic Sugeno sebagai basis algoritma sistem kontrolnya yang dimana prosesnya dimulai dari fuzzifikasi, rule inferensi kemudian defuzzifikasi, serta menggunakan metode Wall Follower sebagai metode untuk navigasinya, dikarenakan untuk menunjang kinerja optimum robot dibutuhkan sistem navigasi serta rancangan yang handal. Robot ini menggunakan Arduino mega2560 sebagai board mikrokontroller, sensor ultrasonik HC-SR04 sebagai pengukur jarak, sensor api sebagai pendeteksi titik api dan sensor garis sebagai pembeda antara home dan target zone, sedangkan software yang digunakan dalam memogram robot adalah Arduino IDE. Pengujian robot yang dibuat dilakukan dengan menggunakan metode blackbox dan bertujuan apakah robot dapat memadamkan api atau tidak. Capaian dari hasil penelitian ini adalah, mengimplementasikan metode fuzzy logic dan wall follower pada robot pemadam api sehingga robot dapat melakukan penelusuran pada arena, memadamkan titik api pada lilin, berhenti dan menjaga jarak dari dinding secara autonomous.
\end{abstract}

Kata kunci : Robot, arduino, pemadam api, fuzzy logic Sugeno, wall follower 


\section{Pendahuluan}

Teknologi berkembang sangat pesat dalam membantu mengatasi masalah-masalah yang dialami oleh manusia. Salah satunya adalah penggunaan robot dalam menjalankan dan melakukan pekerjaan manusia dimana dinilai beresiko tinggi dan membutuhkan ketelitian lebih atau konsistensi yang tidak mungkin dilakukan oleh tenaga manusia. Dengan bantuan robot dalam menjalankan pekerjaan manusia, maka resiko yang diterima manusia bisa dikurangi dan mendapatkan kualitas yang lebih baik serta lebih efisien. Akan tetapi robot diciptakan bukan untuk menggantikan manusia sepenuhnya karena walau bagaimanapun ada pekerjaanpekerjaan tertentu yang tidak dapat digantikan dan diselesaikan oleh robot tanpa bantuan manusia dan begitu pula sebaliknya.

Salah satu masalah yang dapat dikerjakan robot dalam membantu manusia adalah memadamkan api atau kebakaran, resiko yang harus ditanggung oleh tim pemadam kebakaran sangat tinggi. Pekerjaan ini membutuhkan reaksi yang cepat, karena kebakaran dapat dihindari apabila api belum menyebar. Ketika api telah menyebar pekerjaan pemadam kebakaran akan menjadi pekerjaan yang sulit dan beresiko tinggi. Kebakaran merupakan suatu bencana yang dimulai dari suatu titik api yang kemudian menimbulkan kerugian yang sangat tinggi dan bisa terjadi kapan saja. Resiko yang ditimbulkan dari kebakaran dapat berupa kerugian materi dan bisa juga menimbulkan kerugian jiwa. Penanganan kebakaran yang tepat dinilai dapat mengurangi dampak dari bencana kebakaran tersebut. Masalah kebakaran dapat dikurangi apabila sumber api dapat ditemukan dan dipadamkan dalam waktu yang singkat.

Pada penelitian ini penulis mengambil contoh kebakaran di rumah yang sering terjadi untuk disimulasikan dalam sebuah arena yang dibuat penulis. Kemampuan robot dalam menyelesaikan misinya sangat diperhitungkan. Untuk itu sistem navigasi yang handal sangat diperlukan untuk menunjang kinerja optimum robot.

Dari latar belakang tersebut, penulis mencoba menyelesaikan masalah di atas yaitu khususnya pada sistem navigasi robot. Untuk itu penulis mengangkat sebuah judul tugas akhir yaitu : Perancangan robot pemadam api Wall Follower beroda dengan metode Fuzzy Logic (Studi kasus : Simulasi kebakaran pada kompleks perumahan Citraland Kota Palu).

\section{A. Rumusan Masalah}

Berdasarkan permasalahan yang ada, maka rumusan masalah yang penulis rumuskan dalam penelitian ini adalah bagaimana merancang robot pemadam api Wall Follower beroda dengan menggunakan metode Fuzzy Logic.

\section{B. Tujuan Penelitian}

Tujuan yang ingin dicapai oleh penulis dalam penelitian ini adalah dapat merancang robot pemadam api wall follower dengan menerapkan metode fuzzy logic Sugeno sebagai basis algoritma sistem kontrol.

\section{Robot}

Robot berasal dari kata "robota" yang dalam bahasa ceko adalah budak, pekerja atau kuli. Robot merupakan suatu perangkat mekanik yang mampu menjalankan tugas-tugas fisik, baik di bawah kendali pengawasan manusia maupun yang dijalankan dengan serangkaian program yang telah didefinisikan terlebih dahulu. Robot adalah sebuah perangkat mekanik yang dapat melakukan pekerjaan fisik yang dikendalikan secara otomatis atau dikontrol oleh manusia (Rasyid et al., 2016).

\section{Sistem Kontrol}

Sistem kontrol adalah proses pengendalian terhadap beberapa elemen untuk mencapai sasaran atau nilai tertentu. Sistem pada prinsipnya bermaksud untuk mendefinisikan suatu masukan (input) dan keluaran (output). Masukan adalah rangsangan yang dimasukan ke sebuah sistem kontrol dari sumber energi luar agar menghasilkan tanggapan tertentu dari sistem kontrol tersebut. Sedangan keluaran adalah tanggapan yang sebenarnya yang diperoleh sistem kontrol (Pragmawati, 2016).

\section{E. Fuzzy Logic}

Fuzzy logic adalah peningkatan dari logika Boolean yang mengenalkan konsep kebenaran sebagian. Pada logika klasik Boolean dinyatakan bahwa segala hal dapat diekspresikan dalam istilah binary ( 0 atau 1 , hitam atau putih, ya atau tidak). Sementara itu fuzzy logic menggantikan kebenaran boolean dengan tingkat kebenaran. fuzzy logic memungkinkan nilai keanggotaan antara 0 dan 1 , tingkat keabuan dan juga hitam dan putih, dan dalam bentuk linguistik, konsep tidak pasti seperti "sedikit", "lumayan", dan "sangat". Fuzzy logic diperkenalkan oleh Dr. Lotfi Zadeh dari Universitas California, Berkeley pada 1965. Dengan adanya sistem kontrol seperti fuzzy logic ini, perilaku robot akan semakin dinamis dengan adanya istilah tingkat keabuan dalam fuzzy logic itu sendiri. Robot tidak lagi hanya mengenal istilah 0 dan 1 atau hitam dan putih, robot akan terlihat lebih cerdas dalam berbagai kondisi yang akan dibuat. Tahapan dalam fuzzy logic secara umum terdapat 3 proses, yaitu fuzzifikasi, inferensi, dan defuzzifikasi (Azhar et al., 2015).

\section{F. Arduino Mega2560}

Komponen utama di dalam papan Arduino adalah sebuah 8 bit dengan merk ATmega yang dibuat oleh Atmel Corporation. Berbagai papan Arduino menggunakan tipe ATmega yang berbeda - beda tergantung dari spesifikasinya, sebagai contoh Arduino Uno menggunakan ATmega328 sedangkan Arduino Mega 2560 yang lebih canggih menggunakan ATmega2560 (Arifin, 2016).

\section{G. Sensor Ultrasonik}

Sensor ultrasonik dalam robot sebagai pengukur jarak untuk memberikan masukan kapan robot harus 
maju atau harus berbelok, sistem kerja sensor ultrasonik yaitu dengan memancarkan gelombang suara dan memantulkannya jika mengenai objek yang ada di depannya (Rachman et al., 2016).

\section{H. Driver Motor L298 dan Motor DC}

Terdapat beberapa IC yang dapat digunakan sebagai driver motor, salah satunya IC L298. Pada gambar 2.7 terlihat bahwa IC memiliki 4 pin masukan dan 4 pin keluaran dan vcc, vs dan ground. Dua masukan dihubungkan dengan pin arduino untuk mengontrol tegangan maju atau mundur dan 2 pin masukan lagi untuk mengontrol motor yang lainnya (Setiawan, 2016).

\section{Sensor Api}

Flame detectors atau sensor api adalah sebuah sensor yang dapat mendeteksi adanya api. Sensor ini mampu mendeteksi posisi nyala api dengan ketelitian tinggi (hingga nyala api sekecil cahaya lain). Pada sensor ini terdapat sebuah sensor photodioda yang digunakan untuk mendeteksi adanya mata api disekitar sensor tersebut. Sensor ini terdapat 4 pin yaitu pin GND, VCC, Digital Output, dan Analaog Output (Saputra et al., 2016).

\section{J. Arduino IDE}

Arduino diciptakan untuk para pemula bahkan yang tidak memiliki basic Bahasa pemrograman sama sekali karena menggunakan bahasa $\mathrm{C}++$ yang telah dipermudah melalui library. Arduino menggunakan Software Processing yang digunakan untuk menulis program ke dalam arduino. Processing sendiri merupakan penggabungan antara bahasa $\mathrm{C}++$ dan Java. Software arduino ini dapat di-install di berbagai operating system (OS) seperti LINUX, Mac OS, Windows. Arduino tidak hanya sekedar sebuah alat pengembangan, tetapi kombinasi dari hardware, bahasa pemrograman dan Integrated Development Environment (IDE) yang canggih. IDE adalah sebuah software yang sangat berperan untuk menulis program, meng-compile menjadi kode biner dan meng-upload ke dalam memory microcontroller (Arifin, 2016).

\section{K. Visual Studio Code}

Microsoft Visual Studio Code adalah one-stop shop yang memungkinkan kita fokus pada proses pengembangan dan melupakan tools baru. Beberapa fitur Visual Studio Code adalah cross platform, lightweight, powerful editor, code debugging, source control dan integrated terminal (Arumsari, 2019).

\section{Inkscape}

Inkscape adalah sebuah perangkat lunak editor gambar vektor yang bersifat open source dibawah lisensi GNU GPL. Tujuan utama dari inkscape adalah membuat perangkat grafik mutakhir yang memenuhi standar XML, SVG, dan CSS. Inkscape hampir memiliki kesamaan dengan sofware CorelDraw akan tetapi tools dan fitur-fiturnya tidak sama persis, hanya beberapa yang sama (Firda, 2018).

\section{Microsoft Visio}

Microsoft Visio adalah salah satu program yang dapat digunakan untuk membantu diagram. Microsoft Visio menyediakan banyak fasilitas yang membantu anda dalam pembuatan diagram untuk menggambarkan informasi dan sistem dari penjelasan dalam bentuk teks menjadi suatu diagram dalam bentuk gambar disertai penjelasan singkat (Widyatmoko, 2015).

\section{N. Tinkercad}

Tinkercad adalah aplikasi berbasis web yang memungkinkan pengguna untuk membuat desain digital 3D yang siap untuk dicetak. Ya, baik itu objek fisik melalui pencetakan 3D. Bentuk vektor, gambar, dan 2D / 3D dapat diimpor. Sirkuit memungkinkan pengguna untuk mensimulasikan objek yang dibuat. Aplikasi ini pasti memenuhi kebutuhan perancang sederhana yang hanya ingin mendesain objek dari imajinasi dan kemungkinan mencetak model 3D (Supriyanto, 2018).

\section{O. Fritzing}

Fritzing adalah suatu software atau perangkat lunak gratis yang digunakan oleh desainer, seniman, dan para penghobi elektronika untuk perancangan berbagai peralatan elektronika. Antarmuka fritzing dibuat seinteraktif dan semudah mungkin agar bias digunakan oleh orang yang minim pengetahuannya tentang simbol dari perangkat elektronika. Di dalam fritzing sudah terdapat skema siap pakai dari berbagai mikrokontroller Arduino serta shield-nya. Software ini memang khusus dirancang untuk perancangan dan pendokumentasian tentang produk kreatif yang menggunakan mikrokontroller Arduino (Fatoni et al., 2015).

\section{P. Diptrace}

Diptrace adalah software EDA / CAD ini memiliki modul pratinjau 3D real-time built-in dengan kemampuan ekspor STEP dan VRML. Modul pratinjau 3D agak mirip dengan Altium 3D, tetapi sedikit lebih mendasar tanpa mode tampilan single layer dan crosssectional views. DipTrace mengekspor model papan 3D dengan semua komponen yang dipasang ke file STEP, seperti Altium Designer. Ini memberikan integrasi yang cukup bebas gangguan dengan paket MCAD (Khomenko, 2016).

\section{Pembahasan}

\section{A. Metode Penelitian}

Dalam pembuatan penelitian ini, peneliti menggunakan jenis penelitian kualitatif. Penelitian kualitatif sering disebut penelitian naturalistik karena penelitiannya dilakukan pada kondisi yang alamiah. Penelitian kualitatif dilakukan pada objek alamiah yang berkembang apa adanya, tidak dimanipulasi oleh peneliti dan kehadiran peneliti tidak begitu mempengaruhi dinamika pada objek tersebut. Penelitian kualitatif instrumennya adalah peneliti itu sendiri. Menjadi instrument, maka peneliti harus memiliki bekal teori dan wawasan luas, sehingga mampu bertanya, menganalisi, 
memotret, dan mengkonstruksi situasi social yang diteliti menjadi lebih jelas dan bermakna (Ningrum, 2015). Pada penelitian ini data kualitatif yang akan digunakan adalah data - data yang didapatkan dari input sensor - sensor yang digunakan serta output yang akan dihasilkan oleh metode fuzzy logic nantinya.

Pada pengembangan sistem, penulis menggunakan metode pengembangan ADDIE. Model ADDIE adalah istilah sehari-hari yang digunakan untuk menggambarkan pendekatan sistematis untuk pengembangan pembelajaran. ADDIE merupakan singkatan yang mengacu pada proses-proses utama dari proses pengembangan sistem pembelajaran yaitu: analysis (analisis), design (desain), development (pengembangan), implentation (implementasi), dan evaluation (evaluasi) (Hadi, 2016).

Tahapan perancangan desain pemadaman api navigasi Wall Follower beroda menggunakan metode Fuzzy Logic. Tahapan-tahapan tersebut digambarkan pada diagram alir pada gambar 1 sementara untuk sistem kontrol robot digambarkan pada blok diagram gambar 2 . Desain robot lantai 1 dapat dilihat pada gambar 3, lantai 2 dapat dilihat pada gambar 4, dan lantai 3 dapat dilihat pada gambar 5. Adapun desain dari arena robot diambil dari tipe rumah ARUBA pada kompleks perumahan Citraland Kota Palu, dan dapat dilihat pada gambar 6.

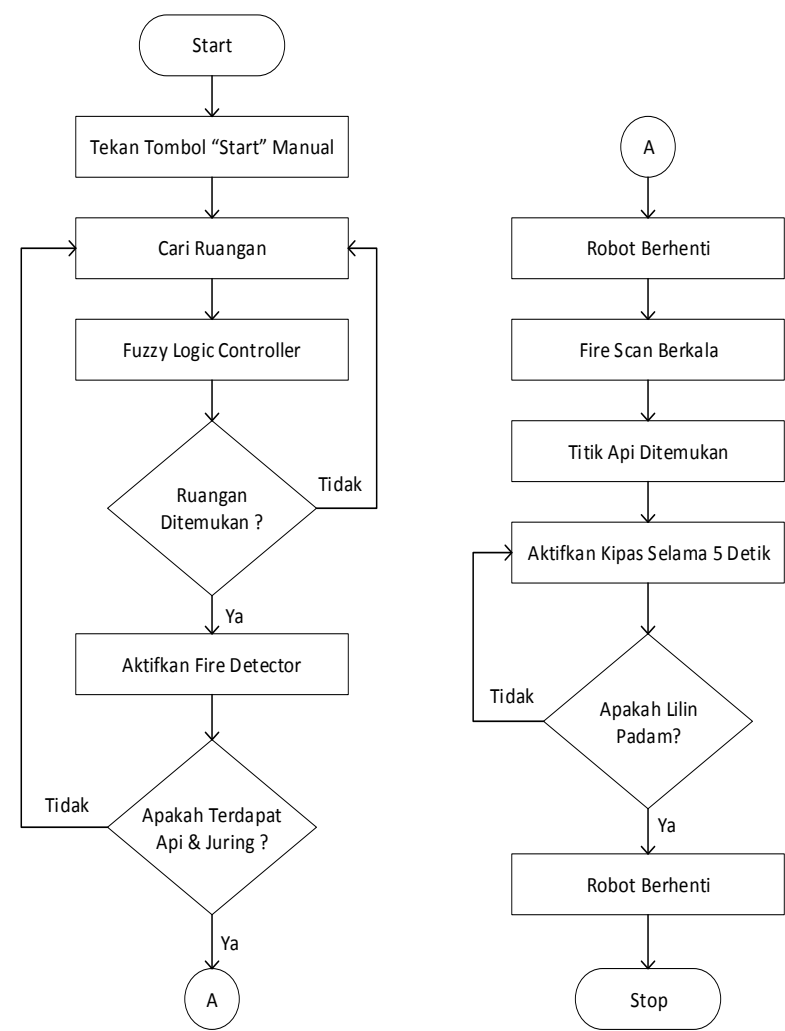

Gambar 1. Flowchart Sistem Pemadaman Api

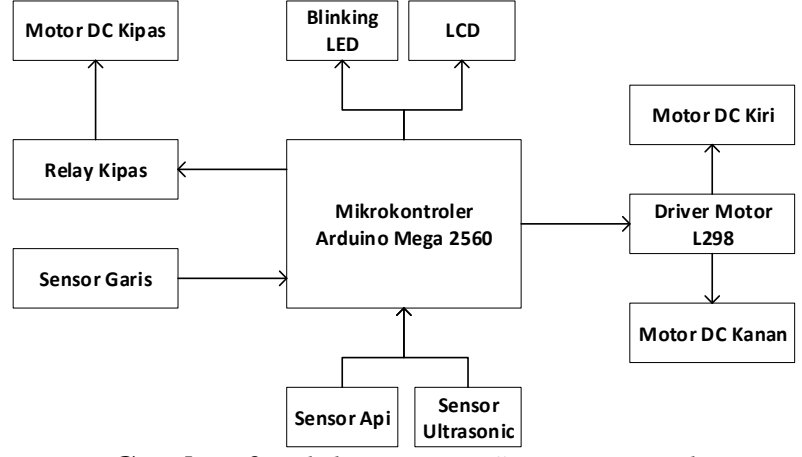

Gambar 2. Blok Diagram Sistem Kontrol

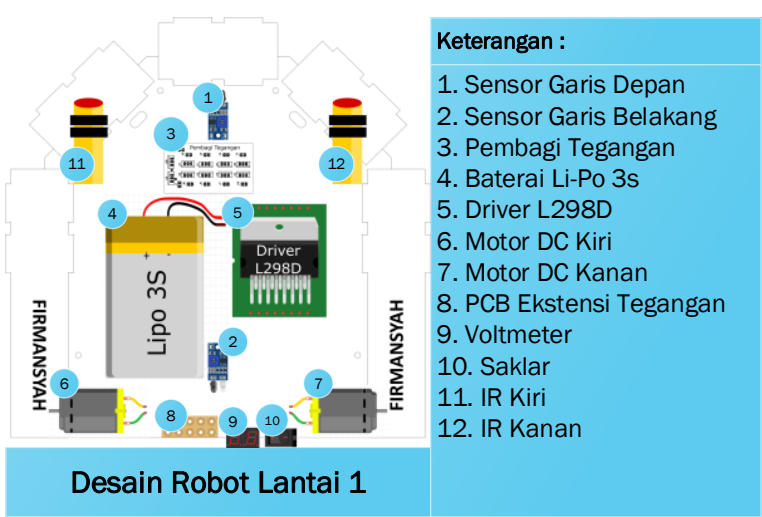

Gambar 3. Desain Robot Lantai 1

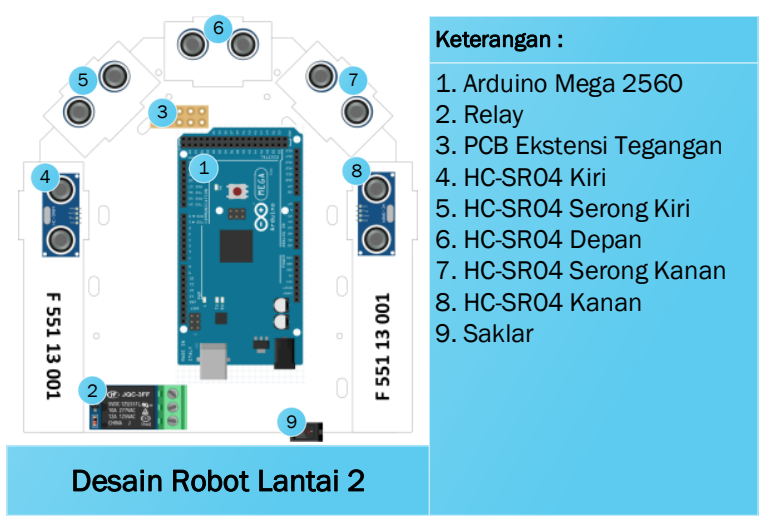

Gambar 4. Desain Robot Lantai 2

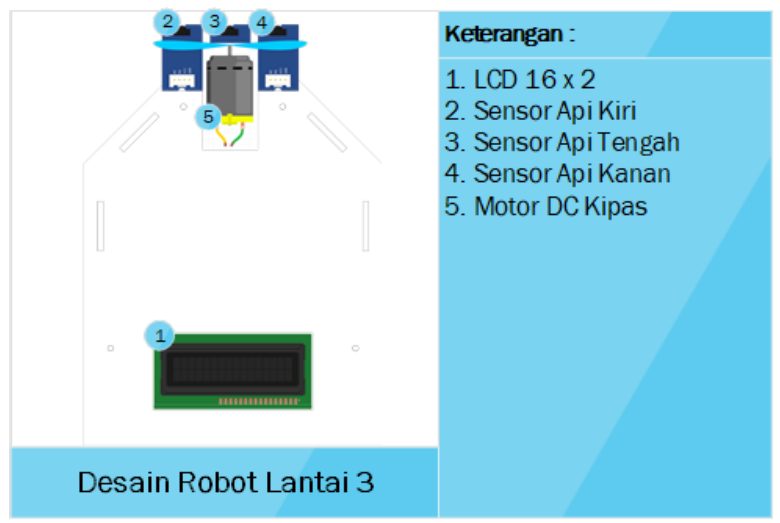

Gambar 5. Desain Robot Lantai 3 


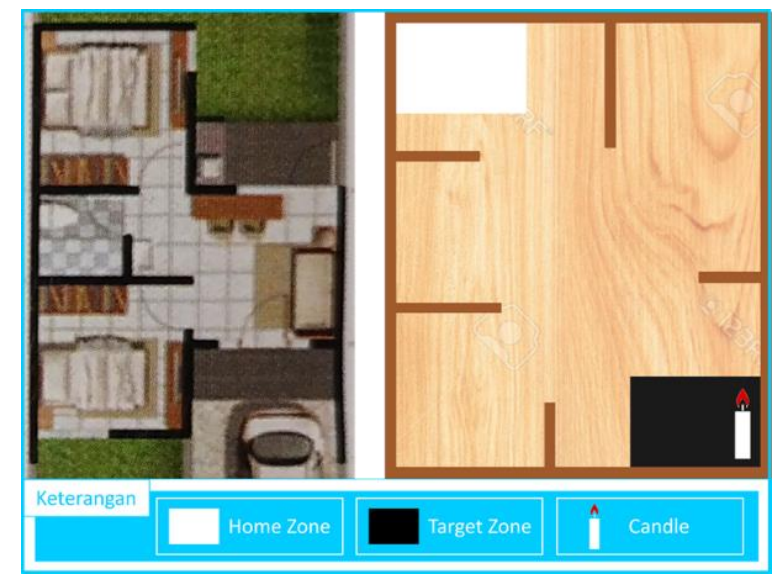

Gambar 6. Desain Arena Robot

\section{B. Konfigurasi Pin Arduino Mega2560}

Konfigurasi pin dari Arduino Mega2560 yang digunakan sebagai mikrokontroler sebagai input dan output, dapat dilihat pada tabel 1 serta gambar 7 dan 8 .

Tabel 1. Konfigurasi Pin Arduino Mega2560

\begin{tabular}{|c|c|c|c|}
\hline No. & $\begin{array}{l}\text { Arduino } \\
\text { Pin }\end{array}$ & $\begin{array}{l}\text { Input / } \\
\text { Output }\end{array}$ & Fungsi \\
\hline 1 & SCL & Output & SCL I2C LCD \\
\hline 2 & SDA & Output & SDA I2C LCD \\
\hline 3 & D10 & Input & Start Switch \\
\hline 4 & D9 & Output & Driver Relay \\
\hline 5 & D8 & Output & Servo \\
\hline 6 & D7 & Output & $\begin{array}{c}\text { Driver Motor } \\
\text { enA }\end{array}$ \\
\hline 7 & D6 & Output & Driver Motor in1 \\
\hline 8 & D5 & Output & Driver Motor in2 \\
\hline 9 & D4 & Output & Driver Motor in3 \\
\hline 10 & D3 & Output & Driver Motor in 4 \\
\hline 11 & D2 & Output & $\begin{array}{c}\text { Driver Motor } \\
\text { enB }\end{array}$ \\
\hline 12 & D42 & Input & IR Kanan \\
\hline 13 & D43 & Input & IR Kiri \\
\hline 14 & D44 & Input & $\begin{array}{c}\text { Echo HC-SR04 } \\
1\end{array}$ \\
\hline 15 & D45 & Output & $\begin{array}{l}\text { Trigger HC- } \\
\text { SR04 } 1\end{array}$ \\
\hline 16 & D46 & Input & $\begin{array}{c}\text { Echo HC-SR04 } \\
2\end{array}$ \\
\hline 17 & D47 & Output & $\begin{array}{l}\text { Trigger HC- } \\
\text { SR04 } 2\end{array}$ \\
\hline 18 & D48 & Input & $\begin{array}{c}\text { Echo HC-SR04 } \\
3\end{array}$ \\
\hline 19 & D49 & Output & $\begin{array}{l}\text { Trigger HC- } \\
\text { SR04 } 3\end{array}$ \\
\hline 20 & D50 & Input & $\begin{array}{c}\text { Echo HC-SR04 } \\
4\end{array}$ \\
\hline 21 & D51 & Output & $\begin{array}{l}\text { Trigger HC- } \\
\text { SR04 } 4\end{array}$ \\
\hline 22 & D52 & Input & $\begin{array}{c}\text { Echo HC-SR04 } \\
5\end{array}$ \\
\hline 23 & D53 & Output & $\begin{array}{l}\text { Trigger HC- } \\
\text { SR04 } 5\end{array}$ \\
\hline
\end{tabular}

\begin{tabular}{|c|c|c|c|}
\hline $\mathbf{2 4}$ & A0 & Input & Sensor Api 1 \\
\hline $\mathbf{2 5}$ & A1 & Input & Sensor Api 2 \\
\hline $\mathbf{2 6}$ & A2 & Input & Sensor Api 3 \\
\hline $\mathbf{2 7}$ & A3 & Input & $\begin{array}{c}\text { Sensor Garis } \\
\text { Depan }\end{array}$ \\
\hline $\mathbf{2 8}$ & A4 & Input & $\begin{array}{c}\text { Sensor Garis } \\
\text { Belakang }\end{array}$ \\
\hline
\end{tabular}

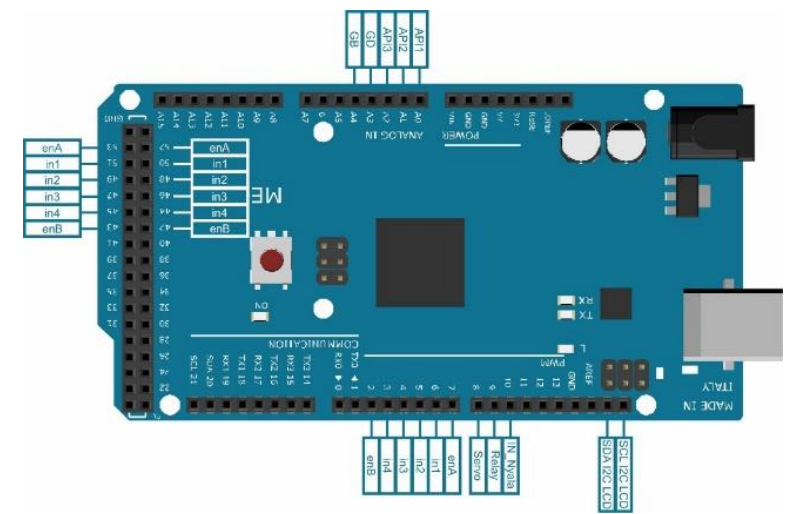

Gambar 7. Konfigurasi Pin Arduino Mega2560

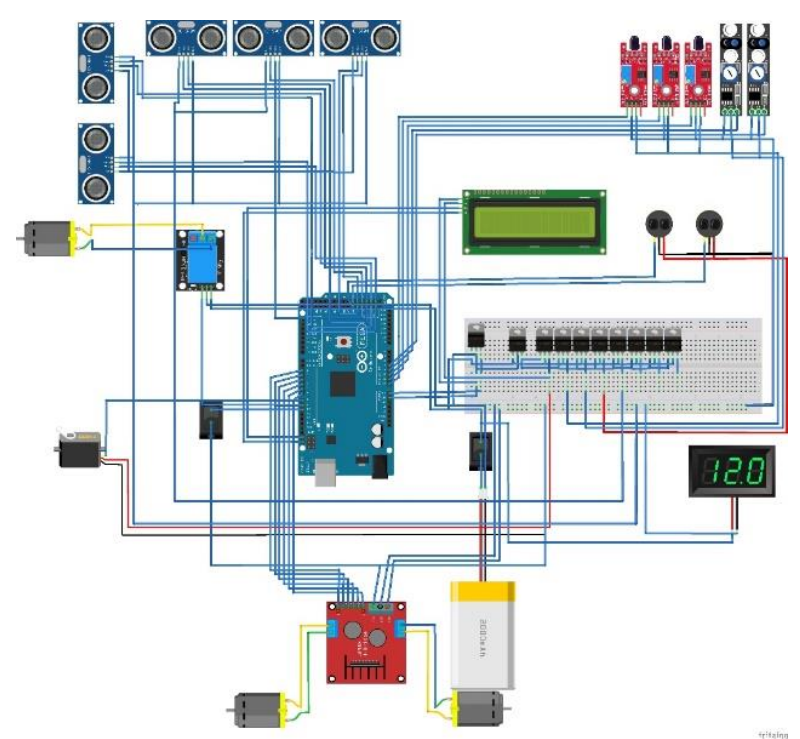

Gambar 8. Robot Schematic

Pin SCL dan SDA menjadi output ke pin SCL dan SDA pada LCD I2C sebagai media menampilkan nilai nilai sensor. Pin D10 menjadi input dari saklar Switch untuk memberi perintah agar robot bisa berjalan. Pin D9 menjadi output ke Driver Relay untuk mengontrol kipas pemadam pada robot. Pin D8 menjadi output ke Servo untuk mengontrol arah kipas pada robot. Pin D7 dan D2 menjadi output ke Driver Motor untuk mengontrol kecepatan dari motor penggerak robot. Pin D6, D5, D4, dan D3 menjadi output ke Driver Motor untuk mengatur arah dari dari motor penggerak robot. Pin D42 dan D43 menjadi input dari sensor Infrared sebagai pendeteksi halangan pada arah depan robot. Pin D44, D46, D48, D50, dan D52 menjadi input echo dari 5 buah sensor ultrasonic HC-SR04 sebagai pengukur jarak pada robot. Pin D45, D47, D49, D51, dan D53 menjadi output trigger dari 5 buah sensor ultrasonic HC-SR04 sebagai pengukur jarak pada robot. Pin A0, A1, A2 menjadi 
input dari Sensor Api sebagai pendeteksi titik api pada lilin yang akan dipadamkan oleh robot nantinya. Pin A3 dan A4 menjadi input dari Sensor Garis sebagai pendeteksi juring di arena robot.

\section{Use Case Diagram}

Use case menggambarkan external view dari sistem yang akan kita buat modelnya. Model use case dapat dijabarkan dalam diagram use case, tetapi perlu diingat, diagram tidak identik dengan model karena model lebih luas dari diagram. Use case harus mampu menggambarkan urutan actor yang menghasilkan nilai terukur (Suendri, 2018).

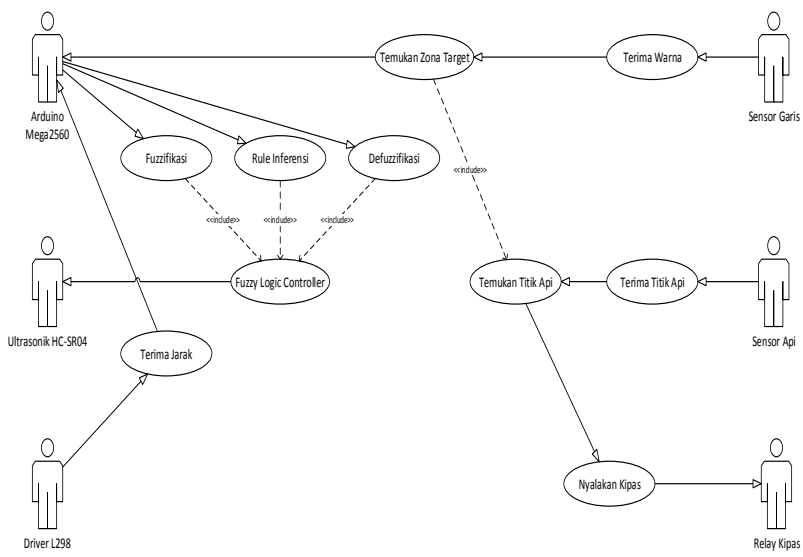

Gambar 9. Use Case Diagram Sistem Robot

\section{Activity Diagram}

Diagram activity menunjukkan aktivitas sistem dalam bentuk kumpulan aksi - aksi, bagaimana masing masing aksi tersebut dimulai, keputusan yang mungkin terjadi hingga berakhirnya aksi. Activity diagram juga dapat menggambarkan proses lebih dari satu aksi salam dalam waktu bersamaan (Suendri, 2018).

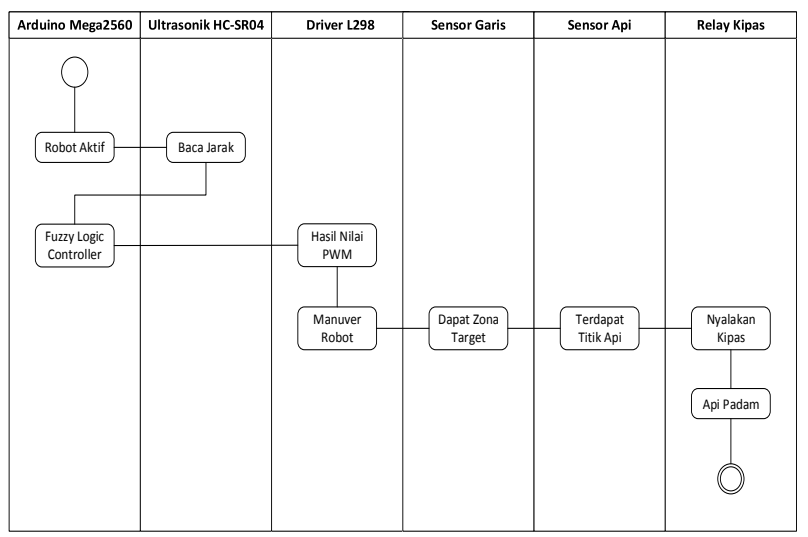

Gambar 9. Activity Diagram Sistem Robot

\section{E. Sequence Diagram}

Secara mudahnya sequence diagram adalah gambaran tahap demi tahap, termasuk kronologi (urutan) perubahan secara logis yang seharusnya dilakukan untuk menghasilkan sesuatu sesuai dengan use case diagram (Suendri, 2018).

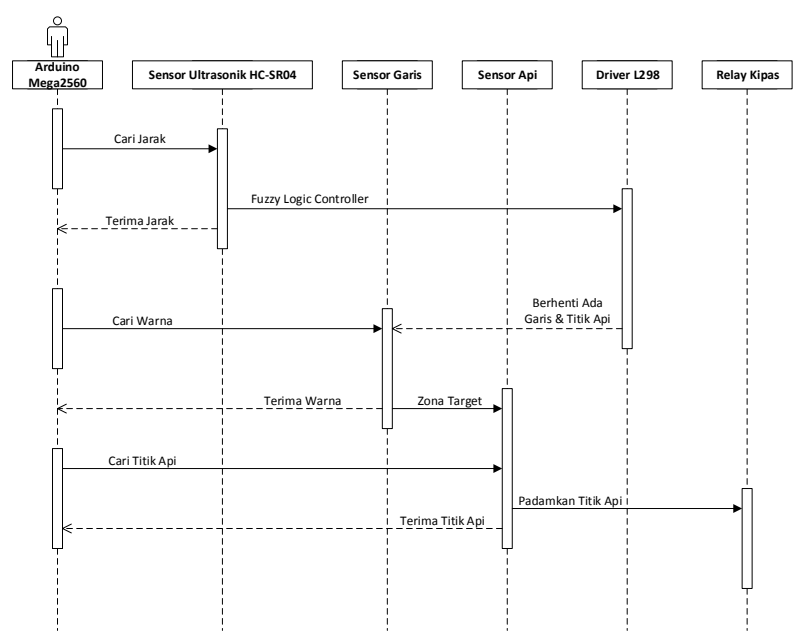

Gambar 9. Sequence Diagram Sistem Robot

\section{F. Terapan Logika Fuzzy}

Pada robot ini menggunakan Metode Fuzzy Logic yang bekerja berdasarkan data input jarak dari Sensor Ultrasonik HC-SR04 yang diterima, kemudian diproses oleh Arduino Mega2560 yang telah menggunakan Fuzzy Logic dan mengontrol arah dan kecepatan pada robot menggunakan Driver Motor L298D. Robot ini menggunakan 2 metode penelusuran, yaitu Metode Inferensi Wall Follower Kanan dan Metode Inferensi Wall Follower Kiri yang dapat dilihat pada tabel 2 dan 3.

Tabel 2. Inferensi Wall Follower Kanan

\begin{tabular}{|c|c|c|c|c|c|}
\hline Rule & $\begin{array}{c}\text { Sensor } \\
\text { Depan }\end{array}$ & $\begin{array}{c}\text { Sensor } \\
\text { Kanan }\end{array}$ & $\begin{array}{c}\text { Sensor } \\
\text { Serong } \\
\text { Kanan }\end{array}$ & $\begin{array}{c}\text { Motor } \\
\text { DC } \\
\text { Kiri }\end{array}$ & $\begin{array}{c}\text { Motor } \\
\text { DC } \\
\text { Kanan }\end{array}$ \\
\hline $\mathbf{1}$ & Dekat & Dekat & Dekat & Pelan & Cepat \\
\hline $\mathbf{2}$ & Dekat & Dekat & Sedang & Pelan & Sedang \\
\hline $\mathbf{3}$ & Dekat & Dekat & Jauh & Cepat & Pelan \\
\hline $\mathbf{4}$ & Dekat & Sedang & Dekat & Pelan & Cepat \\
\hline $\mathbf{5}$ & Dekat & Sedang & Sedang & Pelan & Sedang \\
\hline $\mathbf{6}$ & Dekat & Sedang & Jauh & Cepat & Pelan \\
\hline $\mathbf{7}$ & Dekat & Jauh & Dekat & Cepat & Pelan \\
\hline $\mathbf{8}$ & Dekat & Jauh & Sedang & Pelan & Sedang \\
\hline $\mathbf{9}$ & Dekat & Jauh & Jauh & Cepat & Pelan \\
\hline $\mathbf{1 0}$ & Jauh & Dekat & Dekat & Pelan & Cepat \\
\hline $\mathbf{1 1}$ & Jauh & Dekat & Sedang & Pelan & Sedang \\
\hline $\mathbf{1 2}$ & Jauh & Dekat & Jauh & Sedang & Pelan \\
\hline $\mathbf{1 3}$ & Jauh & Sedang & Dekat & Sedang & Pelan \\
\hline $\mathbf{1 4}$ & Jauh & Sedang & Sedang & Sedang & Pelan \\
\hline $\mathbf{1 5}$ & Jauh & Sedang & Jauh & Cepat & Pelan \\
\hline $\mathbf{1 6}$ & Jauh & Jauh & Dekat & Pelan & Sedang \\
\hline $\mathbf{1 7}$ & Jauh & Jauh & Sedang & Sedang & Pelan \\
\hline $\mathbf{1 8}$ & Jauh & Jauh & Jauh & Cepat & Pelan \\
\hline
\end{tabular}

Tabel 3. Inferensi Wall Follower Kiri

\begin{tabular}{|c|c|c|c|c|c|}
\hline Rule & $\begin{array}{c}\text { Sensor } \\
\text { Depan }\end{array}$ & $\begin{array}{c}\text { Sensor } \\
\text { Kiri }\end{array}$ & $\begin{array}{c}\text { Sensor } \\
\text { Serong } \\
\text { Kiri }\end{array}$ & $\begin{array}{c}\text { Motor } \\
\text { DC } \\
\text { Kiri }\end{array}$ & $\begin{array}{c}\text { Motor } \\
\text { DC } \\
\text { Kanan }\end{array}$ \\
\hline $\mathbf{1}$ & Dekat & Dekat & Dekat & Cepat & Pelan \\
\hline $\mathbf{2}$ & Dekat & Dekat & Sedang & Sedang & Pelan \\
\hline $\mathbf{3}$ & Dekat & Dekat & Jauh & Pelan & Cepat \\
\hline
\end{tabular}




\begin{tabular}{|c|c|c|c|c|c|}
\hline $\mathbf{4}$ & Dekat & Sedang & Dekat & Cepat & Pelan \\
\hline $\mathbf{5}$ & Dekat & Sedang & Sedang & Sedang & Pelan \\
\hline $\mathbf{6}$ & Dekat & Sedang & Jauh & Pelan & Cepat \\
\hline $\mathbf{7}$ & Dekat & Jauh & Dekat & Pelan & Cepat \\
\hline $\mathbf{8}$ & Dekat & Jauh & Sedang & Sedang & Pelan \\
\hline $\mathbf{9}$ & Dekat & Jauh & Jauh & Pelan & Cepat \\
\hline $\mathbf{1 0}$ & Jauh & Dekat & Dekat & Cepat & Pelan \\
\hline $\mathbf{1 1}$ & Jauh & Dekat & Sedang & Sedang & Pelan \\
\hline $\mathbf{1 2}$ & Jauh & Dekat & Jauh & Pelan & Sedang \\
\hline $\mathbf{1 3}$ & Jauh & Sedang & Dekat & Pelan & Sedang \\
\hline $\mathbf{1 4}$ & Jauh & Sedang & Sedang & Pelan & Sedang \\
\hline $\mathbf{1 5}$ & Jauh & Sedang & Jauh & Pelan & Cepat \\
\hline $\mathbf{1 6}$ & Jauh & Jauh & Dekat & Sedang & Pelan \\
\hline $\mathbf{1 7}$ & Jauh & Jauh & Sedang & Pelan & Sedang \\
\hline $\mathbf{1 8}$ & Jauh & Jauh & Jauh & Pelan & Cepat \\
\hline
\end{tabular}

Himpunan Fuzzy Logic pada metode Wall Follower kanan yang digunakan ada 3, yaitu himpunan sensor ultrasonik depan kanan, himpunan sensor ultrasonik samping kanan dan himpunan sensor ultrasonik serong kanan. Himpunan Fuzzy Logic pada metode Wall Follower kiri terdapat 3 himpunan yang juga sama dengan himpunan metode Wall Follower kanan. Adapun himpunan fuzzy yang dimaksud dapat dilihat pada gambar 10, 11 dan 12 untuk Wall Follower kanan dan gambar 13, 14 dan 15 untuk Wall Follower kiri.

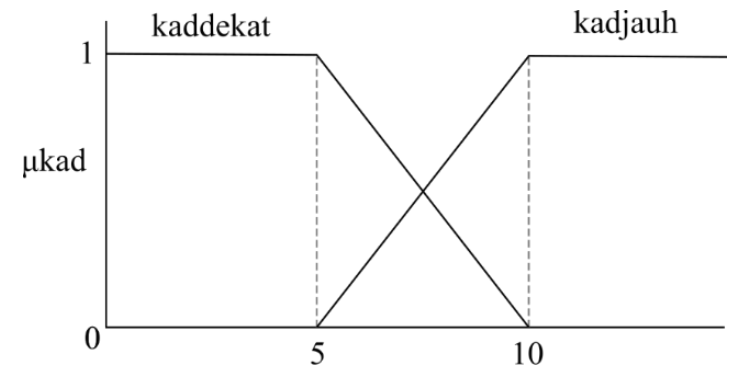

Gambar 10. Himpunan Fuzzy Sensor Depan Kanan

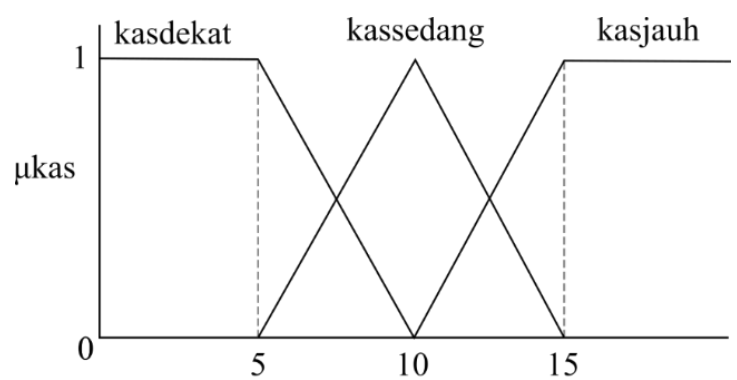

Gambar 11. Himpunan Fuzzy Sensor Samping Kanan

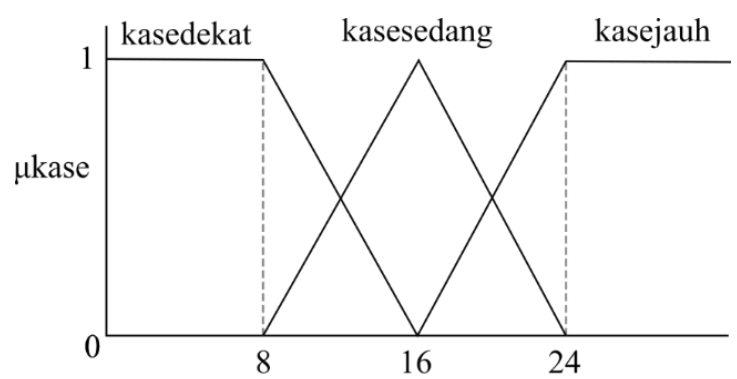

Gambar 12. Himpunan Fuzzy Sensor Serong Kanan

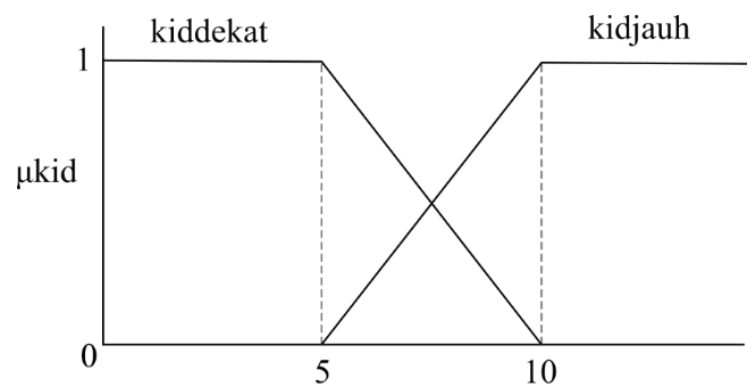

Gambar 13. Himpunan Fuzzy Sensor Depan Kiri

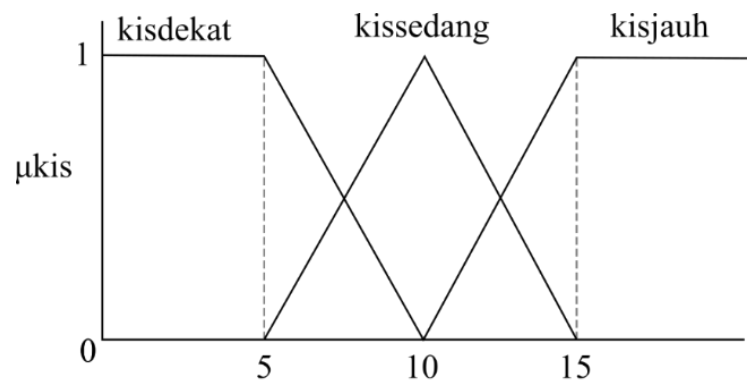

Gambar 14. Himpunan Fuzzy Sensor Samping Kiri

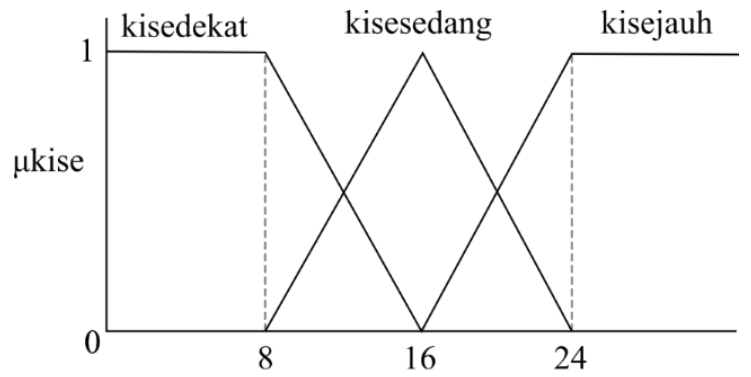

Gambar 15. Himpunan Fuzzy Sensor Serong Kanan

Representasi yang digunakan adalah representasi kurva segitiga yang merupakan gabungan antara 2 garis (linear) seperti pada gambar 16 dan fungsi keanggotaannya pada gambar 17 dan juga menggunakan representasi kurva bahu yang mana daerah yang terletak di tengah-tengah suatu variabel yang direpresentasikan dalam bentuk segitiga, pada sisi kanan dan kirinya akan naik turun. Tetapi terkadang salah satu sisi dari variabel tersebut tidak mengalami perubahan. Himpunan fuzzy "bahu", bukan segitiga, digunakan untuk mengakhiri variabel suatu daerah fuzzy. Bahu kiri bergerak dari benar ke salah, demikian juga bahu kanan bergerak dari salah ke benar yang dapat dilihat pada gambar 18 dan fungsi keanggotaannya pada gambar 19 .

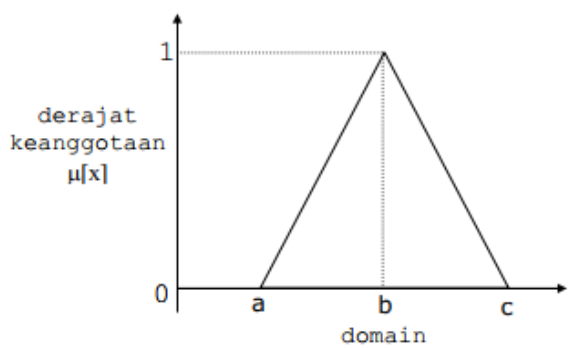

Gambar 16. Representasi Kurva Segitiga 


$$
\mu[x]= \begin{cases}0 ; & x \leq a \text { atau } x \geq c \\ (x-a) /(b-a) ; & a \leq x \leq b \\ (b-x) /(c-b) ; & b \leq x \leq c\end{cases}
$$

Gambar 17. Fungsi Keanggotaan Kurva Segitiga

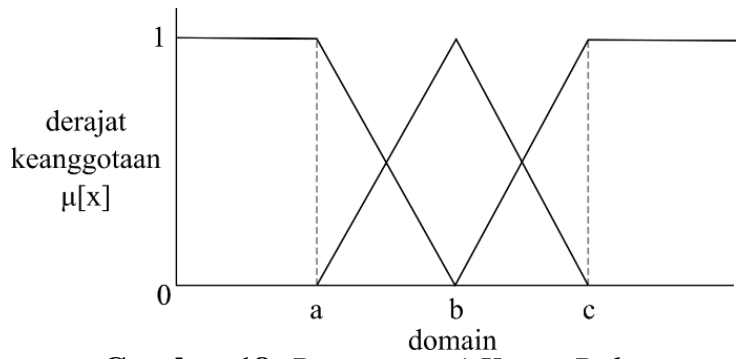

Gambar 18. Representasi Kurva Bahu

$$
\begin{aligned}
& \mu[\mathrm{x}]= \begin{cases}1 & ; \mathrm{x}<=\mathrm{a} \\
(\mathrm{b}-\mathrm{x}) /(\mathrm{b}-\mathrm{a}) & ; \mathrm{a}<\mathrm{x}<\mathrm{b} \\
0 & ; \mathrm{x}>=\mathrm{b}\end{cases} \\
& \mu[x]= \begin{cases}0 & ; \quad \mathrm{x}<=\mathrm{a} \text { atau } \mathrm{x}>=\mathrm{c} \\
(\mathrm{x}-\mathrm{a}) /(\mathrm{b}-\mathrm{a}) & ; \mathrm{a}<\mathrm{x}<\mathrm{b} \\
(\mathrm{c}-\mathrm{x}) /(\mathrm{c}-\mathrm{b}) & ; \mathrm{b}<\mathrm{x}<\mathrm{c}\end{cases}
\end{aligned}
$$

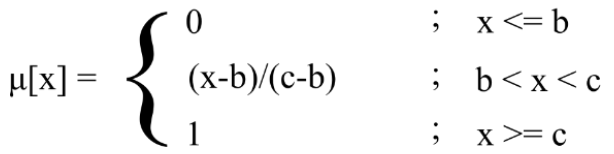

Gambar 19. Fungsi Keanggotaan Kurva Bahu

Fungsi keanggotaan dari sensor depan kanan, sensor samping kanan dan sensor serong kanan dapat dilihat pada gambar 20, 21 dan 22, sedangkan fungsi keanggotaan dari sensor depan kiri, sensor samping kiri dan sensor serong kiri dapat dilihat pada gambar 23, 24 dan 25 .

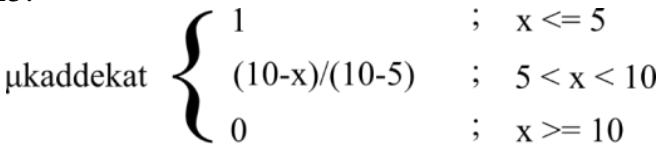

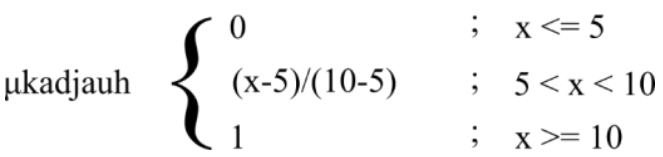

Gambar 20. Fungsi Keanggotaan Sensor Depan Kanan

$$
\begin{aligned}
& \mu \text { kassedang }\left\{\begin{array}{lll}
0 & ; & \mathrm{x}<=5 \text { atau } \mathrm{x}>=15 \\
(\mathrm{x}-5) /(10-5) & ; & 5<\mathrm{x}<10 \\
(15-\mathrm{x}) /(15-10) & ; & 10<\mathrm{x}<15
\end{array}\right. \\
& \text { pkasjauh }\left\{\begin{array}{lll}
0 & ; & \mathrm{x}<=10 \\
(\mathrm{x}-10) /(15-10) & ; & 10<\mathrm{x}<15 \\
1 & ; & \mathrm{x}>=15
\end{array}\right.
\end{aligned}
$$

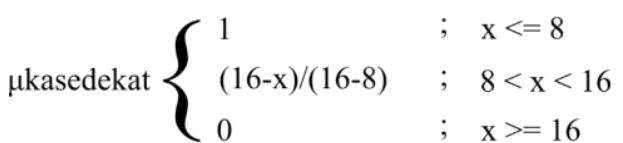

Gambar 21. Fungsi Keanggotaan Sensor Samping Kanan

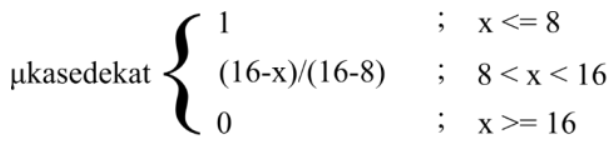

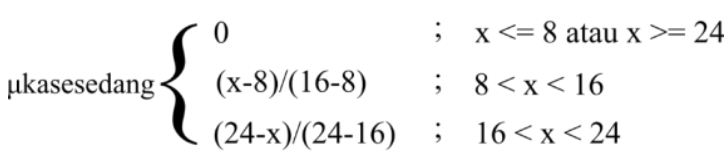

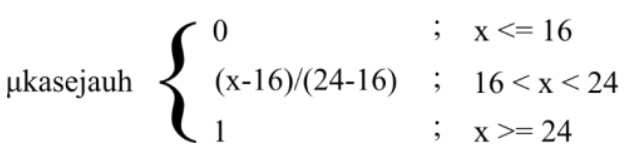

Gambar 22. Fungsi Keanggotaan Sensor Serong Kanan

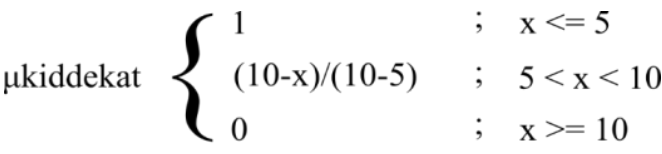

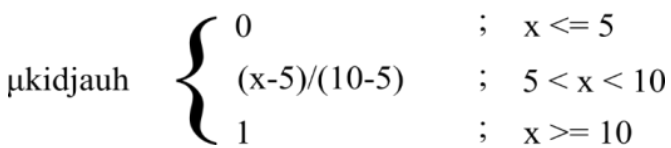

Gambar 23. Fungsi Keanggotaan Sensor Depan Kiri

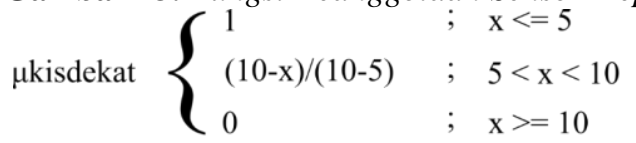

$$
\begin{aligned}
& \mu \text { kissedang }\left\{\begin{array}{lll}
0 & ; & \mathrm{x}<=5 \text { atau } \mathrm{x}>=15 \\
(\mathrm{x}-5) /(10-5) & ; & 5<\mathrm{x}<10 \\
(15-\mathrm{x}) /(15-10) & ; & 10<\mathrm{x}<15
\end{array}\right.
\end{aligned}
$$

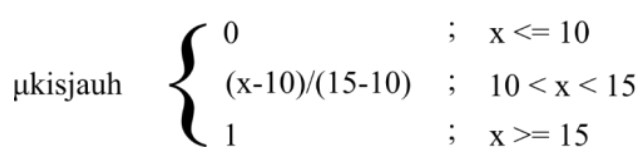

Gambar 24. Fungsi Keanggotaan Sensor Samping Kiri

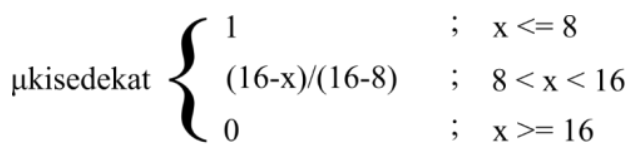

$$
\begin{aligned}
& \text { pkisesedang }\left\{\begin{array}{lll}
0 & ; & \mathrm{x}<=8 \text { atau } \mathrm{x}>=24 \\
(\mathrm{x}-8) /(16-8) & ; & 8<\mathrm{x}<16 \\
(24-\mathrm{x}) /(24-16) & ; & 16<\mathrm{x}<24
\end{array}\right.
\end{aligned}
$$

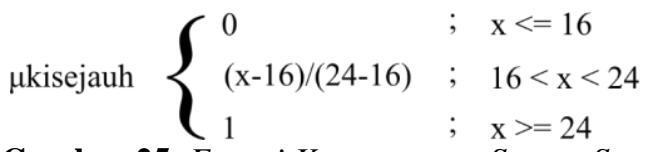

Gambar 25. Fungsi Keanggotaan Sensor Serong Kiri

\section{G. Pengujian Robot}

Pengujian Robot dilakukan dengan melakukan pengujian metode Fuzzy Logic pada arena dengan menggunakan metode Wall Follower kanan dan kiri untuk penelusurannya, pengujian ini menggunakan metode blackbox dan bertujuan untuk mengetahui apakah robot dapat memadamkan api atau tidak, parameter yang digunakan untuk pengujian adalah tegangan $(\mathrm{V})$, berhasil padamkan api (ya / tidak) dan waktu (s). Hasil pengujian dapat dilihat pada tabel 4. 
Tabel 4. Pengujian Robot Pada Arena

\begin{tabular}{|c|c|c|c|c|}
\hline $\begin{array}{c}\text { Per } \\
\text { cob } \\
\text { aan } \\
\text { Ke }\end{array}$ & $\begin{array}{c}\text { Metode } \\
\text { Wall } \\
\text { Follower } \\
\text { Kanan / } \\
\text { Kiri) }\end{array}$ & $\begin{array}{c}\text { Tegang } \\
\text { an }(\mathbf{V})\end{array}$ & $\begin{array}{c}\text { Berhasil } \\
\text { Padamk } \\
\text { an Api } \\
\text { (Ya / } \\
\text { Tidak) }\end{array}$ & $\begin{array}{c}\text { Waktu } \\
\text { (S) }\end{array}$ \\
\hline $\mathbf{1}$ & Kanan & $12.1 \mathrm{~V}$ & Ya & $18.70 \mathrm{~S}$ \\
\hline $\mathbf{2}$ & Kanan & $12.1 \mathrm{~V}$ & Ya & $16.36 \mathrm{~S}$ \\
\hline $\mathbf{3}$ & Kanan & $12.1 \mathrm{~V}$ & Ya & $21.83 \mathrm{~S}$ \\
\hline $\mathbf{4}$ & Kanan & $11.9 \mathrm{~V}$ & Ya & $17.85 \mathrm{~S}$ \\
\hline $\mathbf{5}$ & Kanan & $11.9 \mathrm{~V}$ & Ya & $15.69 \mathrm{~S}$ \\
\hline $\mathbf{6}$ & Kanan & $11.9 \mathrm{~V}$ & Ya & $15.95 \mathrm{~S}$ \\
\hline $\mathbf{7}$ & Kanan & $11.5 \mathrm{~V}$ & Ya & $17.45 \mathrm{~S}$ \\
\hline $\mathbf{8}$ & Kanan & $11.5 \mathrm{~V}$ & Ya & $16.75 \mathrm{~S}$ \\
\hline $\mathbf{9}$ & Kanan & $11.5 \mathrm{~V}$ & Ya & $32.59 \mathrm{~S}$ \\
\hline $\mathbf{1 0}$ & Kanan & $11.1 \mathrm{~V}$ & Ya & $17.84 \mathrm{~S}$ \\
\hline $\mathbf{1 1}$ & Kanan & $11.1 \mathrm{~V}$ & Ya & $19.15 \mathrm{~S}$ \\
\hline $\mathbf{1 2}$ & Kanan & $11.1 \mathrm{~V}$ & Ya & $39.62 \mathrm{~S}$ \\
\hline $\mathbf{1 3}$ & Kiri & $12.1 \mathrm{~V}$ & Ya & $22.85 \mathrm{~S}$ \\
\hline $\mathbf{1 4}$ & Kiri & $12.1 \mathrm{~V}$ & Ya & $23.67 \mathrm{~S}$ \\
\hline $\mathbf{1 5}$ & Kiri & $12.1 \mathrm{~V}$ & Ya & $23.27 \mathrm{~S}$ \\
\hline $\mathbf{1 6}$ & Kiri & $11.9 \mathrm{~V}$ & Ya & $24.09 \mathrm{~S}$ \\
\hline $\mathbf{1 7}$ & Kiri & $11.9 \mathrm{~V}$ & Ya & $22.71 \mathrm{~S}$ \\
\hline $\mathbf{1 8}$ & Kiri & $11.9 \mathrm{~V}$ & Ya & $24.85 \mathrm{~S}$ \\
\hline $\mathbf{1 9}$ & Kiri & $11.5 \mathrm{~V}$ & Ya & $41.98 \mathrm{~S}$ \\
\hline $\mathbf{2 0}$ & Kiri & $11.5 \mathrm{~V}$ & Ya & $23.62 \mathrm{~S}$ \\
\hline $\mathbf{2 1}$ & Kiri & $11.5 \mathrm{~V}$ & Ya & $34.65 \mathrm{~S}$ \\
\hline $\mathbf{2 2}$ & Kiri & $11.1 \mathrm{~V}$ & Ya & $51.99 \mathrm{~S}$ \\
\hline $\mathbf{2 3}$ & Kiri & $11.1 \mathrm{~V}$ & Ya & $27.20 \mathrm{~S}$ \\
\hline $\mathbf{2 4}$ & Kiri & $11.1 \mathrm{~V}$ & Ya & $25.65 \mathrm{~S}$ \\
\hline & & & & \\
\hline
\end{tabular}

Penggunaan fuzzy logic pada penelitian ini difokuskan pada terapannya terhadap sensor ultrasonik dan motor dc dalam menentukan derajat keanggotaannya berdasarkan dari pengukuran jarak yang dilakukan oleh sensor ultrasonik dan hasil dari metode fuzzy logic berupa pengaturan kecepatan motor dc yang akan mempengaruhi manuver dari robot yang dibuat dengan menggunakan metode wall follower kiri atau kanan.

Langkah pertama yang penulis lakukan adalah dengan merancang dan membuat robot yang akan digunakan sebagai terapan dari metode fuzzy logic serta wall follower, kemudian merancang fuzzy logic yang akan diterapkan dimulai dari fuzzifikasi, rule inferensi dan defuzzifikasi. Fuzzifikasi dimulai dengan mengubah variable non non fuzzy (variabel numerik) menjadi variabel fuzzy (variabel linguistik) dengan cara membuat membuat himpunan fuzzy dari masing - masing sensor yang akan digunakan pada metode wall follower kanan dan kiri, selanjutnya membuat fungsi keanggotaan dari masing - masing himpunan fuzzy untuk masing masing metode wall follower yang akan digunakan berdasar dari representasi yang sesuai dengan himpunan fuzzy yang digunakan

Langkah ke-dua adalah membuat rule inferensi untuk masing - masing metode wall follower yang menghasilkan total 36 rule yang mana pada wall follower kanan menggunakan 18 rule dan wall follower kiri menggunakan 18 rule, inferensi wall follower kanan.
Langkah ke-tiga adalah proses defuzzifikasi yaitu dengan mulai mencari alfa predikat pada masing masing 18 rule pada metode wall follower yang digunakan dengan menggunakan fungsi AND atau mengambil nilai terkecilnya yang dapat dilihat pada, kemudian mencari nilai max dari $\mathrm{Z}$ motor dc kiri dan motor dc kanan yang telah kita dapatkan nilainya dari masing - masing rule inferensi metode wall follower yang digunakan, selanjutnya adalah memproses nilai $\mathrm{Z}$ menggunakan metode Sugeno atau mencari nilai Weight Average (rata-rata), dimana nilai akhir pada masing masing motor dc lah yang akan menentukan manuver dari robot pemadam yang dibuat.

\section{Kesimpulan}

Berdasarkan pengujian dan analisis yang dilakukan pada Perancangan robot pemadam api Wall Follower beroda dengan metode Fuzzy Logic (Studi kasus : Simulasi kebakaran pada kompleks perumahan Citraland Kota Palu), maka dapat diperoleh kesimpulan sebagai berikut:

1. Robot dapat mengimplementasikan fuzzy logic pada metode wall follower untuk menelusuri arena yang telah dibuat.

2. Robot dapat menggunakan metode wall follower kanan dan kiri untuk bermanuver di arena.

3. Kecepatan waktu penelusuran arena dipengaruhi oleh beberapa faktor, antara lain yaitu kondisi tegangan dari baterai dan ketebalan dari dinding arena dapat mempengaruhi terjadinya tabrakan pada sudut tipis pada dinding yang dapat menyebabkan waktu penelusuran menjadi lebih lama.

\section{Saran}

Adapun beberapa saran yang bisa diberikan untuk pengembangan lebih lanjut terhadap penelitian ini adalah sebagai berikut:

1. Robot yang dibuat masih bisa dikembangkan lebih lanjut dan dapat menggunakan metode lainnya, seperti metode gabungan Fuzzy Logic \& PID, neurofuzzy, dan odometry.

2. ATMEGA2560 pada Arduino Mega2560 adalah mikrokontroller 8 bit dimana performanya terbatas untuk komputasi kompleks, sebaiknya menggunakan mikrokontroller keluaran terbaru yang mempunyai performa 32 bit seperti mikrokontroller STM32 Arm Cortex.

3. Sensor yang akan digunakan diharapkan menggunakan sensor buatan pabrikan yang telah melalui uji coba standar pada produksinya, contohnya untuk ultrasonik atau sensor jarak bisa menggunakan Parallax PING atau sensor jarak SHARP IR GP2Y, sensor api bisa menggunakan UVTron maupun TPA-81, sedangkan sensor yang digunakan oleh penulis adalah sensor - sensor entry level yang performanya sangat terbatas.

4. Arena yang digunakan dapat dipertebal lagi pada sudut - sudut tipisnya agar mudah terbaca oleh 
sensor yang digunakan, dasar landasan arena disarankan menggunakan papan atau tegel keramik dan pertimbangkan kondisi cahaya yang akan digunakan pada saat robot akan bermanuver yang dapat mempengaruhi pembacaan pada sensor api walaupun tidak signifikan.

\section{Daftar Pustaka}

Rasyid, M. A., Firdaus, \& Derisma. 2016. Rancang Bangun Robot Pengering Lantai Otomatis Menggunakan Metode Fuzzy, Jurnal Sistem Komputer, Universitas Diponegoro, Semarang.

Pragmawati, K. 2016. Sistem Kontrol Peralatan Elektronik Rumah Tangga Menggunakan SMS GATEWAY, Skripsi Fakultas Teknik, Universitas Negeri Semarang, Semarang.

Azhar, A., Kesuma, K. D. W., \& Subagiyo, H. 2015. Perancangan Fuzzy Logic Model Sugeno untuk Wall Tracking Pada Robot Pemadam Api, Jurnal ELEMENTER, Politeknik Caltex Riau, Pekanbaru.

Arifin, J., Zulita, L. N., \& Hermawansyah. 2016. Perancangan Murottal Otomatis Menggunakan Mikrokontroler Arduino Mega 2560, Jurnal Media Infotama, Universitas Dehasen, Bengkulu.

Rachman, F. Z., \& Yanti, N. 2016. Robot Penjejak Ruangan Dengan Sensor Ultrasonik Dan Kendali Ganda Melalui Bluetooth, Jurnal Teknologi Terpadu, Politeknik Negeri Balikpapan, Balikpapan.

Setiawan, D. 2016. Rancang Bangun Robot Mobil Kontrol Sederhana Menggunakan Arduino Berbasis Android System, Jurnal Sains, Teknologi dan Industri, Universitas Lancang Kuning, Pekanbaru.

Saputra, D. H. et al. 2016. Pembuatan Model Pendeteksi Api Berbasis Arduino Uno Dengan Keluaran SMS Gateway, Prosiding Seminar Nasional Fisika (EJournal), Institut Pertanian Bogor, Bogor.

Arumsari, M. 2019. Microsoft Visual Studio Code: Seperti Apa Fiturnya?, https://blog.dicoding.com/microsoft-visual-studiocode/, diakses : 14 Juli 2019.

Firda. 2018. Apa itu Inkscape? Mengenal Software Inkscape, https://www.ngoprakit.tech/2018/06/apaitu-inkscape-mengenal-software.html, diakses : 14 Juli 2019.

Widyatmoko, K. \& Rumteh, E. E. 2015. Sistem Informasi Pemesanan Tiket Pada Floo Tour And Travel Berbasis Web, Jurnal EPrints UdiNus Repository, Universitas Dian Nuswantoro, Semarang.

Supriyanto. 2018. Aplikasi Desain 3D untuk Membuat Character http://wwwmarilahcoding.com/2018/07/aplikasidesain-3d-dengan-dukungan .html, diakses : 14 Juli 2019.

Fatoni, A., Nugroho, D. D., \& Irawan, A. 2015. Rancang Bangun Alat Pembelajaran Berbasi ATMega 328 Di Universitas Serang Raya, Jurnal PROSISKO, Universitas Serang Raya, Serang.
Khomenko, V. 2015. Under Review: EAGLE and DipTrace PCB Design Tools for 3D Previews, https://www.electronicdesign.com/dev-tools/underreview-eagle-and-diptrace-pcb-design-tools-3dpreviews, diakses : 14 Juli 2019.

Ningrum, A. O. C. 2015. Analisis Pengamen Jalanan Di Kota Surakarta (Studi kasus Pengamen Jalanan di Kota Surakarta), Skripsi Fakultas Keguruan Dan Ilmu Pendidikan, Universitas Muhammadiyah Surakarta, Surakarta.

Hadi, H., \& Agustina, S. 2016. Pengembangan Buku Ajar Geografi Desa-Kota Menggunakan Model ADDIE, Jurnal Educatio, STKIP Hamzanwadi Selong, Lombok Timur.

Suendri. 2018. Impelementasi Diagram UML (Unified Modelling Language) Pada Perancangan Sistem Informasi Remunerasi Dosen Dengan Database Oracle (Studi Kasus : UIN Sumatera Utara Medan), Jurnal Ilmu Komputer dan Informatika, Universitas Islam Negeri Sumatera Utara, Medan. 